\title{
ポーラスコンクリートブロックに封入された \\ 有用微生物群と土壤中の脱窒菌との \\ 共生による水質浄化 \\ WATER QUALITY PURIFICATION BY THE SYMBIOSIS OF \\ USEFUL MICROBIAL GROUP IN THE POROUS CONCRETE BLOCK \\ AND DENITRIFYING BACTERIA IN SOIL
}

\author{
松永信博 1 -増田壮佑 2 -中牟田大嗣 3 ・徳永貴久 4 \\ Nobuhiro MATSUNAGA, Sousuke MASUDA, Taishi NAKAMUTA, Takahisa TOKUNAGA \\ 矢野真一郎 5 - 押川英夫 6 - 橋本彰博 7 - 藤田和夫 8 \\ Shinichiro YANO , Hideo OSHIKAWA , Akihiro HASHIMOTO, Kazuo FUJITA \\ 古賀雅之 ${ }^{9}$ ・岩下智明 10 ・原田敦彦 11 \\ Masayuki KOGA , Toshiaki IWASHITA , Atsuhiko HARADA \\ 1正会員 工博 九州大学大学院 総合理工学研究院教授（广816-8580 福岡県春日市春日公園6-1） \\ 2非会員 三菱重工業＼cjkstart株式会社（广672-8035 兵庫県姫路市飾磨区中島 $1350 ）$ \\ 3 学生員 九州大学大学院 総合理工学府（T816-8580 福岡県春日市春日公園6-1) \\ 4正会員 博 (工) 佐賀大学 低平地研究センター講師（广840-8502 佐賀県佐賀市本庄町1) \\ 5 正会員 博 (工) 九州大学大学院 工学研究院准教授（广812-8581 福岡県福岡市西区元岡744番地） \\ 6正会員 博 (工) 九州大学大学院 工学研究院助手（T812-8581 福岡県福岡市西区元岡744番地) \\ 7 正会員 博 (工) 九州大学大学院 工学研究院学術研究員 ( \\ 8正会員 九州大学大学院 工学研究院（广812-8581 福岡県福岡市西区元岡744番地） \\ 9非会員コヨウ 株式会社（†835-0006 福岡県山門郡瀬高町大字坂田169） \\ 10非会員＼cjkstart株式会社ビッグバイオ（†862-0962 熊本県熊本市田迎6丁目11-55） \\ 11非会員 NP0法人 河川環境基金（广816-0063 福岡県福岡市博多区金隈1丁目28-45）
}

\begin{abstract}
Laboratory experiments were carried out on water quality purification with EcoBio-Block (EBB). EBB is a porous concrete block including Bacillus subtilis natto group. In this study, we examined experimentally denitrification effect of EBB by letting it live together with denitrification bacteria in soil. The time variations of TN, ON, DIN, $\mathrm{NH}_{4}-\mathrm{N}, \mathrm{NO}_{2}-\mathrm{N}$, and $\mathrm{NO}_{3}-\mathrm{N}$ were obtained under the aerated condition by changing the weight ratio of EBB to water. On the basis of those data, the denitrification rate, the mineralization rate, and the decreasing rate of DIN were obtained. As a result, we confirmed that the processes of organic matter decomposition, nitrification, and denitification were performed effectively by the symbiosis of useful microbial group and denitrifying bacteria.
\end{abstract}

Key Words : EcoBio-Block, water quality purification, laboratory experiments

\section{1.はじめに}

近年の急激な人間活動の活発化により，自然の水質浄 化システムは崩壊している. 生活排水や工業排水等によ る有機物や栄養塩の過剩な負荷が，河川，湖沼，沿岸域 等の自然水域の水質を悪化させ，水質污濁をはじめさま ざまな問題を引き起こしている1).これらの過剩な負荷に よる水環境の悪化を防ぐには，水域に流入する負荷量を 抑えることが重要であるが, 下水道整備や高次排水処理
には莫大な費用と時間が必要となる．このような状況下 で，我々は自然のシステムを修復しながら人間と自然の 共生を可能と寸る革新的な水質改善技術が求められてい る. 特に, 生態系の持つ物質循環システムを有効利用寸 ることで，水域の負荷を減少させようという取り組みが 有望視されている(2)，3)，4).

著者ら ${ }^{5), 6)}$ は, 多孔型コンクリートブロック内に耐アル カリ性をもつ有用微生物群を封入し, 有機污濁の進行し た水域の水質を高効率に浄化する環境ブロックの開発に 
取り組んでいる.このブロックはエコバイオ・ブロック (EBB) と呼ばれている. その水質浄化機能のメカニズムは 未だ不明な点はあるものの, EBB中の有用微生物群 (以下, EBB菌と呼ぶ）が，水中に存在する様々な菌と互いに補完 しあう関係を保つことで，単菌では得られない優れた自 然浄化能力を有していることを明らかにした.

本研究の目的は, 試料水の溶存酸素濃度を飽和状態に 保ち, 水槽の床に敷き詰めた底泥とEBBとの相互作用によ り，系における脱窒機能がどのように促進されるかにつ いて調べると共に，水質の経時変化を実験的に明らかに することにある.

\section{2. 実験概要}

\section{（1）EBBの性状}

EBBとは，有用微生物群を封入したポーラスコンクリー トブロックのことである. ここで, 有用微生物群とは, 土袞中に生息する納豆菌群 (Bacillus subtilis natto group) を抽出・培養し，耐アルカリ性を持たせたものである．代 表的なEBBを図-1 に示す．形状は， $100 \mathrm{~mm} \times 100 \mathrm{~mm} \times 60 \mathrm{~mm}$ の直方体形状である．EBB菌およびEBBの性状について以 下に示寸.

・ EBB菌はpH3〜11程度までの範囲で生存できるため, セメントペースト中への封入が可能である.

- $\mathrm{EBB}$ 菌の有効な増殖可能温度帯は $10 \sim 65^{\circ} \mathrm{C}$ であるこ とから, 水温が日変動や季節変動により激しく変化 する自然界においても水質浄化機能を発揮するこ とが十分期待できる.

・ EBBはポーラス構造のコンクリートブロックであり, 水との接触面積が非常に大きいことに加え, 封入さ れたEBB菌は直径 $10 \sim 100 \mu \mathrm{m}$ の無数の穴を通じて水 中の有機物を分解することができる.

著者ら ${ }^{5), 6)}$ は, これまでフランビンによる閉鎖系と水槽 を用いた開放系において, EBBの基本性能実験を行ってき た. $E B B に よ る$ 有機物分解能力および硝化能力は，市販 されている通常のコンクリートブロックに比べ著しく大 きく, 富栄養化した水域の水質浄化に有効であることを 示した. また，水温が高くなるにつれ，EBBによる有機物

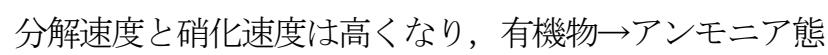
窒素 一硝酸態窒素という無機化プロセスが高効率に行わ

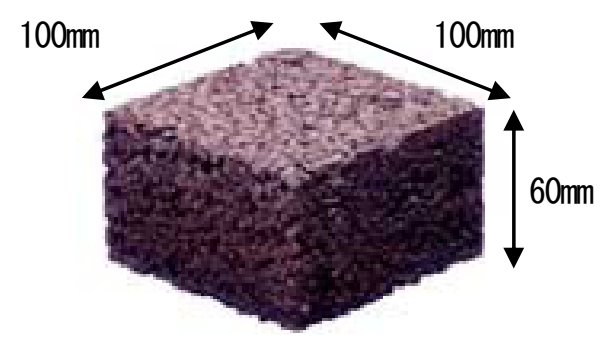

図-1 EcoBio-Block

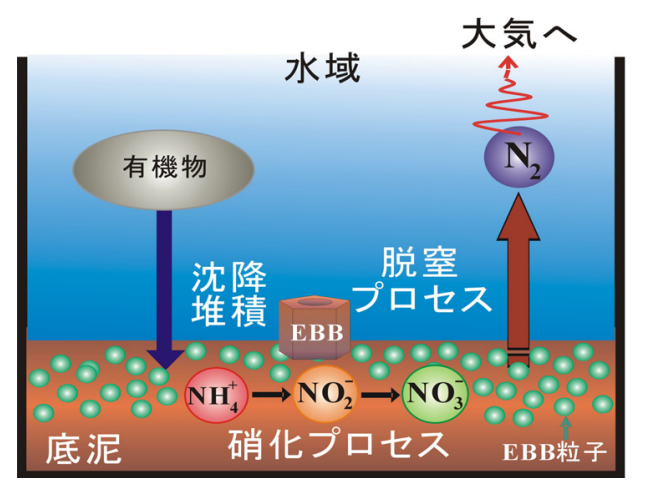

図-2 EBB の水質浄化プロセス

れることを明らかにした，図一2は，水域における有機物 分解 $\rightarrow$ 硝化 $\rightarrow$ 脱窒プロセスを模式的に示したものである. EBBに封入された有用微生物群と土㙵中の脱窒菌との共 生により, 有機物の分解と無機化プロセスが促進され, 硝酸態窒素の生成が促進されれば，脱窒プロセスも活性 化し，水質浄化が著しく進むものと期待される.

\section{（2）実験方法}

実験には，九州大学筑紫キャンパス内にある池の水を 試料水として用いた．試料水の採水を2006年10月23日に 行った. 水槽の底に敷き詰める底泥として, 福岡県大宰 府市にある水田の土を用いた，EBB粒子は，EBB-OCT（約 $800 \mathrm{~g})$ と呼ばれる中空円筒状のものを粒径 $10 \mathrm{~mm}$ 程度の粒 子状に砕いて使用した．実験では，4l水槽を9個用意し， 水田の土 $520 \mathrm{~g}$ をれぞれの水槽の底に敷き詰めた。 $\mathrm{EBB}$ の投入質量を表-1に示寸ように8通り設定した。 それら を8個の水槽内の土の表面上に一様に置いた. それぞれの 水槽に試料水を $3 \ell$ 注入して水質の経時変化を調べた. 残 りの 1 つの水槽には，リファレンスとして，土と試料水 のみが投入された. EBB粒子を投入した場合の水質の経時 変化とリファレンスの水質を比較することにより, EBB による水質浄化能力を評価した. 設定した（ブロック・ 水）質量比を表-1に示す. 試料水 $36 に$ 対LEBB粒子を $25 \mathrm{~g}$ 投入した場合の実験を基本実験としてEBB 1.0 と呼び, EBB粒子を 50 g投入した場合をEBB 2.0のようにEBB 0.5〜 EBB 8.0までEBB投入量を変化させた.

水温は恒温装置で $20^{\circ} \mathrm{C} に$ 保たれており，暗条件下にお くことで植物プランクトンの光合成による一次生産は抑 えられた. また, エアーポンプで常に曝気することで試 料水のDO濃度は飽和状態に保たれた. 約1ヶ月間にわたつ て, 定期的に各水槽功毎回約 $50 \mathrm{~m} 1$ の試料水を採水し,

表-1 (ブロック・水) 質量比

\begin{tabular}{|c|c|c|c|}
\hline & EBB投入量 $(g)$ & 試料水量 (I) & (ブロック·水)質量比 $\left(\times 10^{-2}\right\rfloor$ \\
\hline EBB 0.5 & 12.5 & 3 & 0.42 \\
\hline EBB 1.0 & 25 & 3 & 0.83 \\
\hline EBB 1.5 & 37.5 & 3 & 1.25 \\
\hline EBB 2.0 & 50 & 3 & 1.67 \\
\hline EBB 4.0 & 75 & 3 & 2.5 \\
\hline EBB 5.0 & 100 & 3 & 3.33 \\
\hline EBB 6.0 & 150 & 3 & 5 \\
\hline EBB 8.0 & 200 & 3 & 6.67 \\
\hline
\end{tabular}


表-2 初期試料水の性質

\begin{tabular}{|c|c|c|c|}
\hline $\mathrm{pH}$ & Chl.a[jg/l] & Pheo.[pg/l] & $\mathrm{BOD}_{5}[\mathrm{mg} / \mathrm{l}]$ \\
\hline 7.86 & 24.83 & 9.37 & 7.28 \\
\hline $\mathrm{COD}[\mathrm{mg} / \mathrm{l}]$ & $\mathrm{TN}[\mathrm{mg} / \mathrm{l}]$ & $\mathrm{TP}[\mathrm{mg} / \mathrm{l}]$ & $\mathrm{NH}_{4}-\mathrm{N}[\mathrm{mg} / \mathrm{l}]$ \\
\hline 9.4 & 1.69 & 0.102 & 0.002 \\
\hline
\end{tabular}

$\mathrm{NO}_{2}-\mathrm{N}[\mathrm{mg} / \mathrm{l}] \mathrm{NO}_{3}-\mathrm{N}[\mathrm{mg} / \mathrm{l}] \mathrm{PO}_{4}-\mathrm{P}[\mathrm{mg} / \mathrm{l}] \mathrm{SiO}_{2}-\mathrm{Si}[\mathrm{mg} / \mathrm{l}]$

水質分析を行うことで水質の経時変化を調べた.

水質の測定項目は，形態別栄養塩類（TN, TP, $\mathrm{NH}_{4}-\mathrm{N}$, $\left.\mathrm{NO}_{2}-\mathrm{N}, \mathrm{NO}_{3}-\mathrm{N}, \mathrm{PO}_{4}-\mathrm{P}, \mathrm{SiO}_{2}-\mathrm{Si}\right) ， \mathrm{DO}$ 濃度， $\mathrm{pH}$ である。形 態別栄養塩類は，TN・TP Auto Analyzerにより測定され た. DO濃度はポータブル溶存酸素計 (東覀DKK DO-24P)，

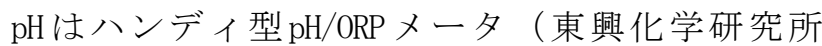
TPX-90SiN）を用いて測定した。初期水におけるCh1. a濃 度とPheo. 濃度は試料水 $500 \mathrm{ml}$ をガラス繊維濾紙(Whatman

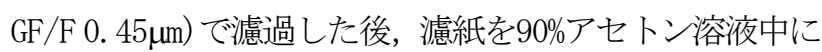
入れ, 得られた抽出液をLorenzenの方法 ${ }^{7)}$ に従って分析 した. 初期試料水の生物化学的酸素要求量(BOD) と化学的 酸素要求量 $(C O D)$ の測定は工業用水試験方法 ${ }^{8)}$ に沿って 行われた. $\mathrm{BOD}_{5}$ を測定する際のDO濃度の測定はウインク ラー法を用いた. CODの測定には過マンガン酸カリウム酸 性法 $\left(\mathrm{KMnO}_{4}\right.$ 法)を用いた。

\section{3. 実験結果}

\section{（1）水質の経時変化}

実験開始時における試料水の水質を表-2に示す. クロ ロフィルa(Chl. a) 濃度とフェオフィチン (Pheo. ) 濃度は, それぞれ $24.8 \mu \mathrm{g} / 1,9.4 \mu \mathrm{g} / 1$ という值をとっており，初 期の試料水には植物プランクトンが通常の河川と比べて 多く存在していたことがわかる. BOD 5 の值とCODの值はそ れぞれ7. $28 \mathrm{mg} / 1,9.40 \mathrm{mg} / 1$ という值をとっており, BOD について,アユ等貧腐食性水域の水産物用など に利用できる水の環境基準においては， $3 \mathrm{mg} / 1$ 以下とされている点からも, 本実験に用いた試 料水の值はこの基準を大きく上回っており, 有 機物量が多く含まれていることがわかる. また, 平成 18 年の全国一級河川における総空素平均と総リン平均はそ れぞれ $0.4 \mathrm{mg} / 1,0.03 \mathrm{mg} / 1$ 程度となっており, それに比心゙ るとTNは1. 69mg/1, TPは0.105mg/1とそれぞれ3〜4倍程度 の大きな值をとっている. 溶存態無機窒素濃度 $(\mathrm{DIN}=$ $\left.\mathrm{NH}_{4}-\mathrm{N}+\mathrm{NO}_{2}-\mathrm{N}+\mathrm{NO}_{3}-\mathrm{N}\right)$ と溶存態無機リン濃度 $\left(\mathrm{DIP}=\mathrm{PO}_{4}-\mathrm{P}\right)$ について見てみると, それぞれほぼ0～ 0.01 程度であり， 比較的小さな值を示していると考えられる。これは，採 水時には植物プランクトンが大量に増殖しており，すで に栄養塩が吸収されたためと考えられる. 一方，个イ酸 態ケイ素濃度についてはかなり高い值を示している.こ れらのデータから実験に用いた試料水はかなり有機污濁 していたことがわかる.
図-3（a），（b）にそれぞれDO濃度とpHの経時変化を示 す. DO濃度の変化から常にエアーポンプで曝気すること により，試料水中のDO濃度は飽和状態に維持されている ことが確認できる. コンクリートブロックが高アルカリ 性のためEBBの投入量が多くなるにつれて $\mathrm{pH}$ 值が高くな る傾向にある.しかし, pH值は7.5〜8.5の間にあり, pH の変化による水質への影響はそれほど大きくないと考え られる。

図-4（a）～（f）にそれぞれ形態別窒素濃度（TN，0N， DIN, $\left.\mathrm{NH}_{4}-\mathrm{N}, \mathrm{NO}_{2}-\mathrm{N}, \mathrm{NO}_{3}-\mathrm{N}\right)$ の経時変化を示す. 図中のデ 一タは各実験值からリファレンスの值を差し引いた值で ある．TN濃度の值は時間とともに増加し，実験開始後 20 日後くらいから減少し始める。 DIN濃度の経時変化は $\mathrm{NO}_{3}-\mathrm{N}$ 濃度の分布と類似しており，時間とともに増加する 傾向が認められる，有機態窒素 (ON) 濃度の值はTN濃度 からDIN濃度を引くことにより算定されている. TN濃度の 分布とON濃度の分布から, 初期段階におけるTN濃度の増 加はEBBからの有機物の分解・溶出に起因していると考え られる. 一方，20日目以降に見られるTN濃度の減少は脱 窒による低下と考えられる。

溶存態窒素 $\left(\mathrm{NH}_{4}-\mathrm{N}, \quad \mathrm{NO}_{2}-\mathrm{N}, \mathrm{NO}_{3}-\mathrm{N}\right)$ 濃度の経時変化に ついて見てみると，EBB 6.0，EBB 8.0において実験開始 から10日後までの期間で急激に有機物分解が起こり， $\mathrm{NH}_{4}-\mathrm{N}$ 濃度が徐々に増加している. 10 日目以降は硝化活性 が高まり $\mathrm{NH}_{4}-\mathrm{N}$ 濃度が減少し, 代わりに $\mathrm{NO}_{2}-\mathrm{N}$ 濃度が増加し ている. 13 日目以降は増加した $\mathrm{NO}_{2}-\mathrm{N}$ 濃度が減少し $\mathrm{NO}_{3}-\mathrm{N}$
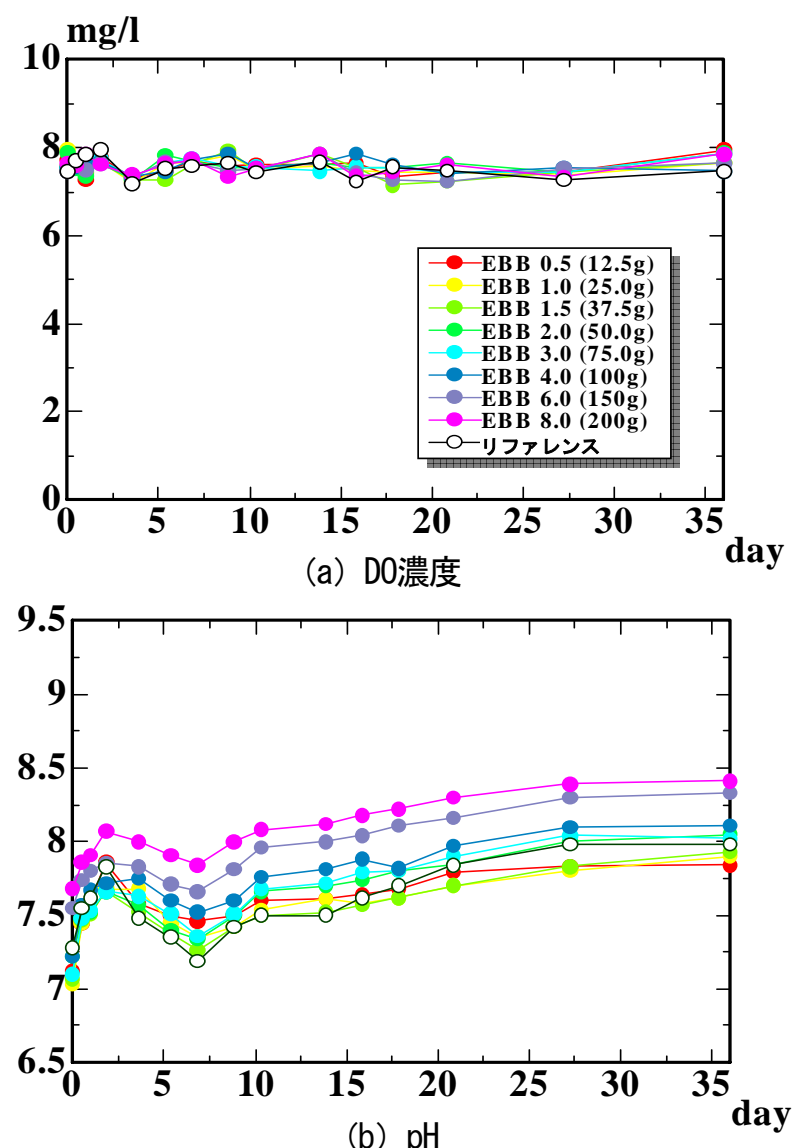

図-3 水質の経時変化 


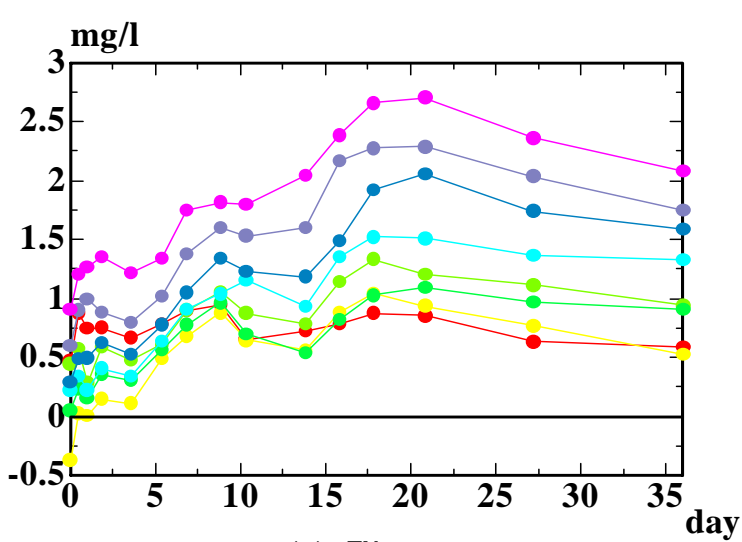

(a) TN

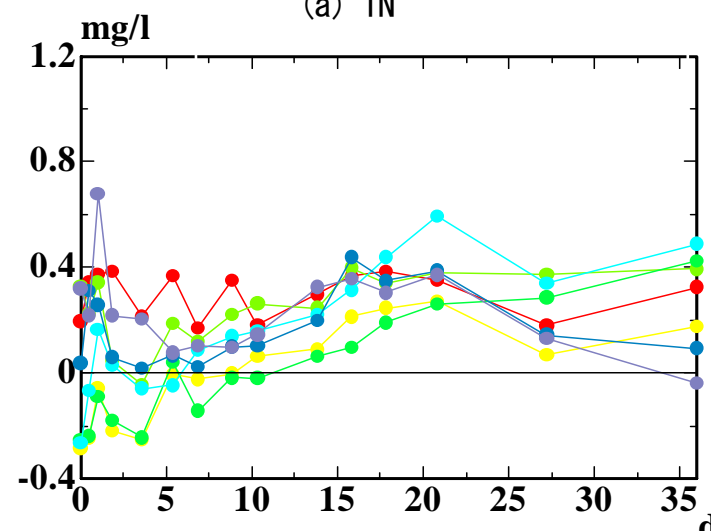

(c) DIN

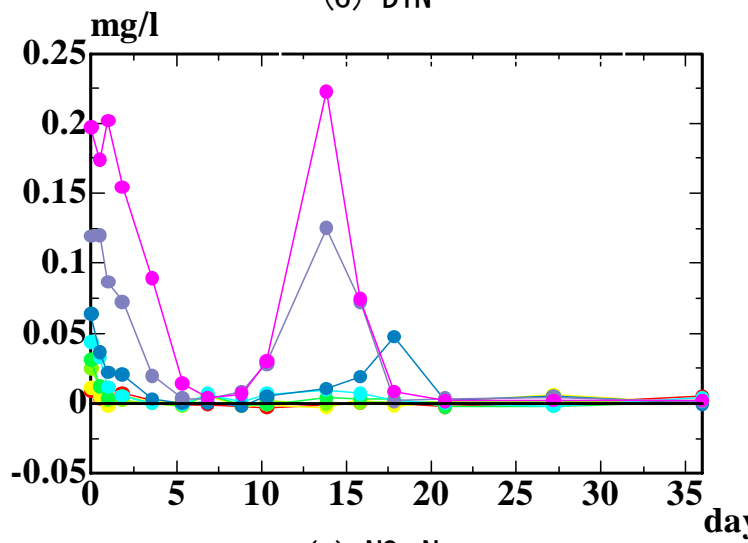

(e) $\mathrm{NO}_{2}-\mathrm{N}$
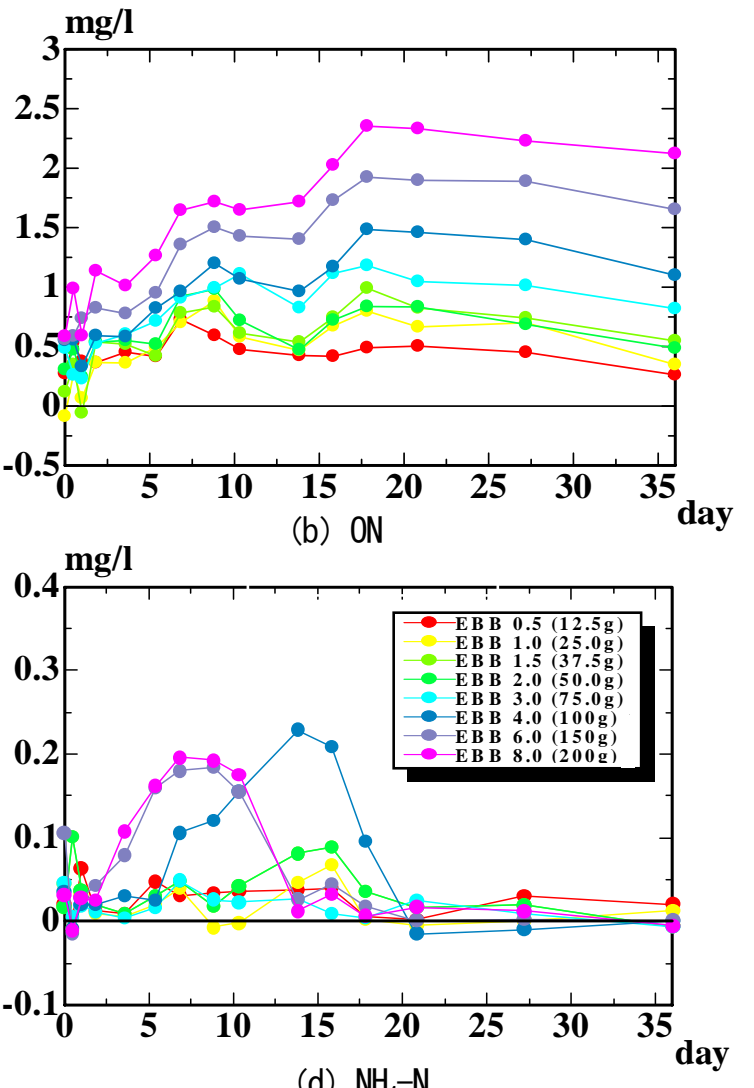

(d) $\mathrm{NH}_{4}-\mathrm{N}$

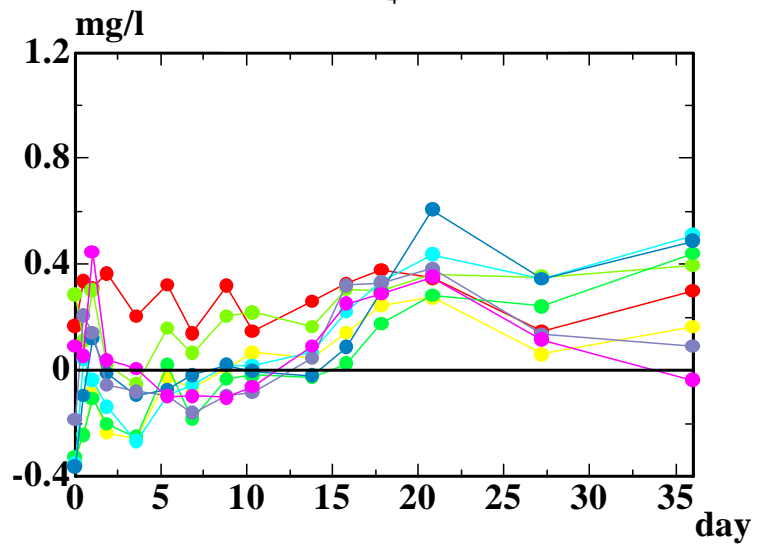

(f) $\mathrm{NO}_{3}-\mathrm{N}$

図-4 各形態別窒素濃度（TN, ON, DIN, $\mathrm{NH}_{4}-\mathrm{N}, \quad \mathrm{NO}_{2}-\mathrm{N}, \quad \mathrm{NO}_{3}-\mathrm{N}$ ）の経時変化

(上闵のデータはすべてリファレンスを差し引いた值)

濃度が増加している. 22 日目以降は $\mathrm{NO}_{3}-\mathrm{N}$ 濃度がほぼ停滞 が減少傾向を示している. 土壌中の脱窒菌が存在しなけ れば $\mathrm{NO}_{3}-\mathrm{N}$ 濃度が増加するはずであるが， TN濃度の值が 減少していることから硝酸態窒素が脱窒され大気中に抜 けていることが推測される. EBB 4.0においてはEBB 6.0, EBB 8.0に比べ有機物分解・硝化のプロセスともにやや遅 れて現れていることがわかる. EBB 0.5〜EBB 3.0におい ても值は小さいが同じ傾向がみられる. 図-4（e) で示さ れた $\mathrm{NO}_{2}-\mathrm{N}$ 経時変化において, 初期に見られるピークは, EBBから試料水中に溶出したものと思われる. 溶出した $\mathrm{NO}_{2}-\mathrm{N}$ は直ちに硝化され $\mathrm{NO}_{3}-\mathrm{N} に$ 変化したと考えられる.

溶存態無機窒素濃度（DIN）の経時変化は10～20日目ま では増加傾向を示しているが，その後は脱窒作用により EBB1.5と2を除いてほとんどが減少傾向を示している.

TN濃度の経時変化は, EBBの投入量が多くなるにつれ内
部にEBB菌の餌として封入されている有機物量が多くな るため, 投入量に比例して高い值を示している. EBB内に 封入されている有機物の溶出は実験開始から15～20日目 まで続くが，その後は，硝酸態窒素の供給により脱窒活 性が高まっていることがわかる. また, その効果はブロ ック投入量に比例して高くなっていることがわかる. EBB 菌は好気性であり，脱窒菌は嫌気性である.この両者が 共生して脱窒活性を高めるためには，水域のどこかに低 酸素領域が形成される必要がある。著者らは，現時点で はEBB粒子と底泥との接触面において貧酸素領域が形成 されているものと考えている.

ON濃度に関しては，EBBの投入量が多くなるにつれ内 部に封入されている有機物量が多くなるため, TN濃度と 同様に投入量に比例して高い值を示している. 有機物の 溶出が抑えられ，脱窒活性が高まった実験開始後 20 日以 
降に減少傾向を示していることから, 脱窒活性が高まっ た状態においても有機物分解・硝化能力は高い状態を維 持しており, 硝酸態窒素を絶えず生成している状態であ るといえる.

$\mathrm{NH}_{4}-\mathrm{N}$ 濃度は初期に急激に増加し, その後減少して $\mathrm{NO}_{2}-\mathrm{N}$ 濃度と $\mathrm{NO}_{3}-\mathrm{N}$ 濃度が増加している。 従って, DO濃度が高い 状態に維持されている水域においては, EBBを施工すると 初期に急激な有機物分解が起こり，そこで発生したアン モニア態窒素が硝化され，亜硝酸態窒素，硝酸態窒素に 変化することがわかる. 初期に $\mathrm{NH}_{4}-\mathrm{N}$ 濃度は急激に増加し, その後減少する. 有機物が分解して発生したアンモニア 態窒素は，硝化菌が活性化するまでは増加するが，硝化 菌が活性化した後は，アンモニア態窒素は直ちに硝化さ れ, 亜硝酸態窒素, 硝酸態窒素と変化する. 有機物分解 はブロック投入量の増加に伴い促進され，分解速度は増 加寸る. 続いて行われる硝化も有機物分解による影響を うけ，ブロック投入量が増加するにつれ活性が高まるま での時間が早くなっている傾向が見られる. このように, 土㙵中の脱窒菌とEBB菌を共生させた状態でも，EBBの高 い有機物分解能力と硝化能力は発揮されていることがわ かる.

\section{（2）形態別窒素の関係式}

全窒素 (TN) ，有機態窒素 (ON)，無機態窒素（DIN） および大気中に放出される窒素 $\left(\mathrm{N}_{2}\right)$ との間には, 次式 で示される保存則が成立する.

$$
[T N]=[O N]+[D I N]+\left[N_{2}\right]
$$

ここで $[\mathrm{a}]$ は物質 $\mathrm{a}$ の量を示寸記号である. 脱窒量 $\left[\mathrm{N}_{2}\right]$ まで考慮した場合， [TN] は保存されることから

$$
\frac{d[T N]}{d t}=0=\frac{d[O N]}{d t}+\frac{d[D I N]}{d t}+\frac{d\left[N_{2}\right]}{d t}
$$

となる. 従って,

$$
\frac{d[\mathrm{ON}]}{d t}=-\frac{d[\mathrm{DIN}]}{d t}-\frac{d\left[\mathrm{~N}_{2}\right]}{d t}
$$

で与えられる.ここで, $\mathrm{d}[\mathrm{ON}] / \mathrm{dt}$ は有機態窒素生成速度, $\mathrm{d}[\mathrm{DIN}] / \mathrm{dt}$ は無機態窒素生成速度, $\mathrm{d}\left[\mathrm{N}_{2}\right] / \mathrm{dt}$ は脱窒速度 である.

本実験では， $\left[\mathrm{N}_{2}\right]$ が測定されていないことより

$$
[T N]_{E}=[O N]+[D I N]
$$

という関係が成り立つ. ここで, $[\mathrm{TN}]_{\mathrm{E}}$ は本実験で得ら れた全窒素量であり，保存量ではないことに注意する. 従って，両辺を時間で微分すると

$$
\frac{d[T N]_{E}}{d t}=\frac{d[O N]}{d t}+\frac{d[D I N]}{d t} \neq 0
$$

$$
\text { となる.（3)式と(5)式から }
$$

$$
\frac{d\left[N_{2}\right]}{d t}=-\frac{d[T N]_{E}}{d t}
$$

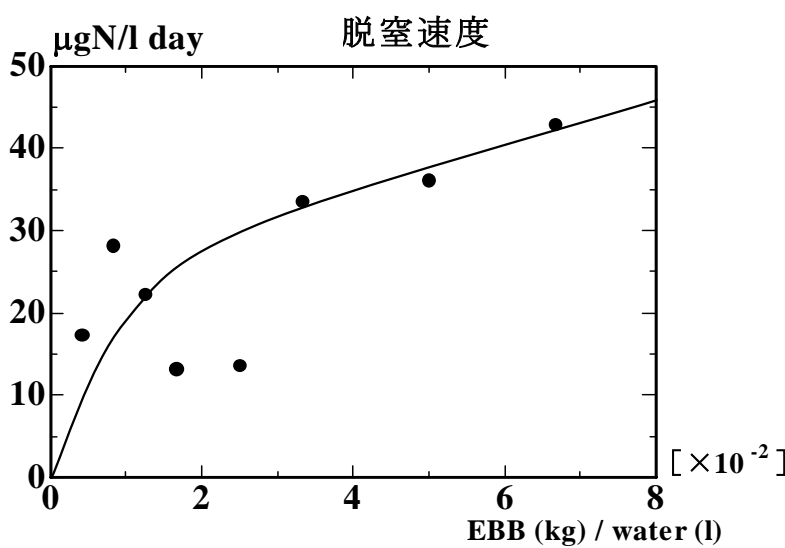

図-5 脱窒速度と（ブロック・水）質量比の関係

(上図のデータはすべてリファレンスを差し引いた值)

脱空速度： $\frac{d\left[N_{2}\right]}{d t}=-\frac{d[T N]_{E}}{d t}$

有機物生成速度：

$$
\begin{aligned}
\frac{d[\mathrm{ON}]}{d t} & =-\frac{d[\mathrm{DIN}]}{d t}-\frac{d\left[\mathrm{~N}_{2}\right]}{d t} \\
& =-\frac{d[D I N]}{d t}+\frac{d[T N]_{E}}{d t}
\end{aligned}
$$

DIN生成速度 $: \frac{d[D I N]}{d t}$

となる。

\section{（3）脱窒速度}

図-4（a）で示されたTN濃度の分布において，20日以 降のTN濃度の減少率に (7) 式を当てはめ, 脱窒速度を求め た. 図-5 は, そのようにして求めた脱窒速度を(ブロッ ク・水）質量比に対してプロットしたものである. 図中 の実線で示されるように（ブロック・水）質量比が増加 するにつれ脱窒速度は増加する傾向が見られる.これは, EBBによる硝化作用により, 硝酸態窒素が十分供給され， 脱窒菌が活性化したためと考えられる. 図-4 で示された すべてのデータでは, EBBを投入していないリファレンス の結果が差し引かれている. 従って図中の実線は（ブロ ック・水）質量比が0の時, 脱窒速度が0 となるように 引かれている. これは，以下で示寸無機化速度及びDIN 生成速度においても同様である。

\section{（4）無機化速度}

無機化速度は有機物分解速度 $\mathrm{d}[\mathrm{ON}] / \mathrm{dt}$ に負符号をつ けたものに等しい. 図-4 (b) で示されたON濃度の経時変 化において，20日以降の減少率を求め，無機化速度を算 定した. 図-6 は無機化速度を（ブロック・水）質量比に 対してプロットしたものである. データにばらつきはあ るものの, 図中の実線が示すように無機化速度は（ブロ ック・水) 質量比が増加するにつれ減少する傾向が見ら れる. (ブロック・水) 質量比が大きくなるにつれ, 有 


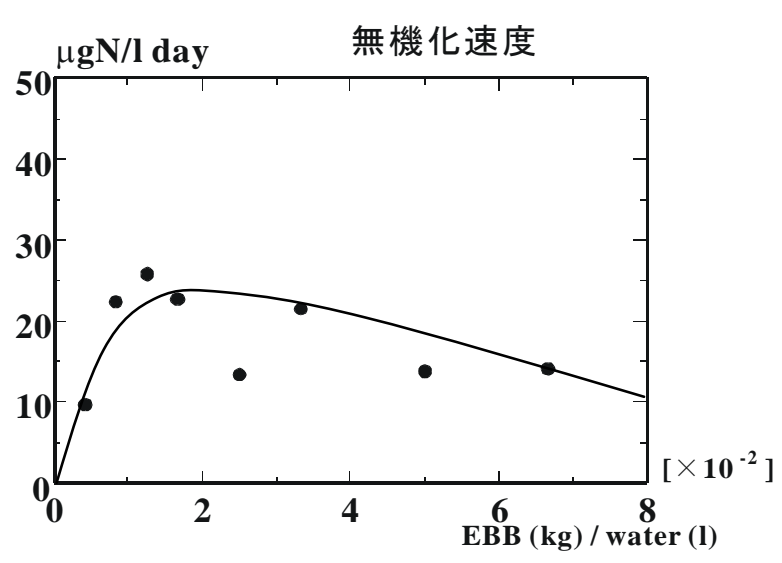

図-6 無機化速度と（ブロック・水）質量比の関係 (上図のデータはすべてリファレンスを差し引いた值)

機物分解速度が増加するというこれまでの結果5), 6) と矛 盾寸るが，これに関しては，今後更なる実験を行い，検 討していく予定である.

\section{（5）DIN生成速度}

実験開始20日以降におけるDIN生成速度は，図-4（C) で示されたDIN濃度の経時変化に基づいて算定された。 EBB1.5と2を除いて20日以降のDIN濃度は減少しており， $\mathrm{d}[\mathrm{DIN}] / \mathrm{dt}$ は負值となる．時間的にDIN濃度が減少する ということは，脱窒速度が有機物分解速度よりも大きい ことを意味している．図-7ではd[DIN ]/dt の絶対值を

(ブロック・水) 質量比に対してプロットしたもので, DIN減少速度と（ブロック・水）質量比の関係を表してい る. 今回の実験に置いては, 図中の実線が示すようにDIN 減少速度は（ブロック・水）質量比とともに線形的に増 加していることがわかる.

\section{4. おわりに}

EBB菌と脱窒菌を共生させ, 試料水のDO濃度を飽和状態 に保ち，（ブロック・水）質量比を種々変化させること でEBBの有機物分解能力および脱窒能力を調べた. 得られ た結果は以下の通りである.

1) ポーラスコンクリートブロック内に封入 された有用微生物群と土壤脱窒菌との共 生により有機物分解 $\rightarrow$ 硝化 $\rightarrow$ 脱窒プロセ スが効率的に行われることが確かめられ た。

2 ) 脱窒速度は（ブロック・水）質量比が増加 するにつれて増加する傾向がある。

3 ）無機化速度は,（ブロック・水）質量比が 増加するにつれ減少する傾向が得られた が，この点に関しては今後詳細な実験を行 って確かめて行きたい.

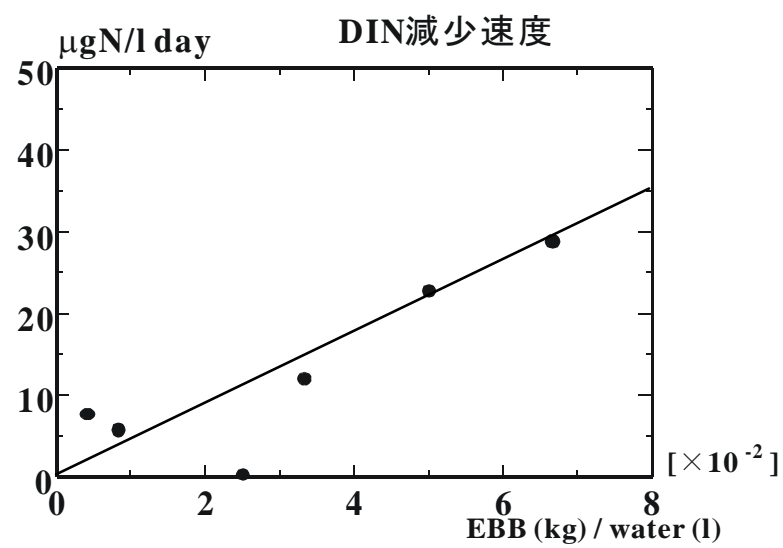

図-7 DIN減少速度と（ブロック・水）質量比の関係 (上図のデータはすべてリファレンスを差し引いた值)

4 ）無機態窒素濃度（DIN）は時間とともに減 少しており，今回の実験においてはEBBに よる有機物分解速度よりも脱窒速度のほ うが勝っていた。

謝辞 : 本研究は，平成18年度建設技術研究開発助成制度 の助成（代表者 松永信博）を受けて行われた。 また， 室内実験および氷質分析を行うにあたり高橋篤氏に多大 なる協力を受けた。ここに記して感謝の意を表します。

\section{参考文献}

1） 高橋鉄哉，藤原建紀，久野正博，杉山陽一: 伊勢湾におけ る外洋系水の進入深度と貧酸素水塊の季節変動, 海の研究, 9, pp. 223-236, 2000.

2）須藤隆一:環境修復のための生態工学, 講談社, pp. 22-28, 2001.

3）池田佳子，荒木佐知子，熟谷いら゙み：浚渫へドロを利用し た水辺の植生復元の可能性の検討, 保全生態学研究, Vol. 4, pp. 21-31, 1999.

4）羽田好孝：アオサの除去による浜名湖の水質浄化対策，水 学シリーズ 水産業における水圈環境保全と修復機能，恒 星社厚生閣，pp. 106-118， 2002.

5）松永信博，徳永貴久，増田壮佑，矢野真一郎，押川英夫， 藤田和夫, 古賀雅之, 岩下智明, 原田敦彦: エコバイオ・ ブロック (EBB) の水質净化機能に関する基礎的実験, 水工学 論文集 $(2006)$ ，第50巻，pp. 1081-1086.

6）松永信博, 増田壮佑, 中牟田大嗣, 徳永貴久, 矢野真一郎, 押川英夫, 藤田和夫, 古賀雅之, 岩下智明, 原田敦彦: 納 豆菌群を封入した多孔型コンクリートブロックによる水質 浄化能力, 水工学論文集 (2007), 第51巻, pp. 1415-1420.

7) Lorenzen , C. J . : Determination of Chlorophyll and Pheo-Pigments:Spectrophotometric Equation, Limnology and Oceanography(1967), Vol. 12, No. 2, pp. 343-346.

8) 日本分析化学会北海道支部 : 水の分析, 第5版, 化学同人, pp. 290-303， 2005.

(2007. 9. 30受付) 